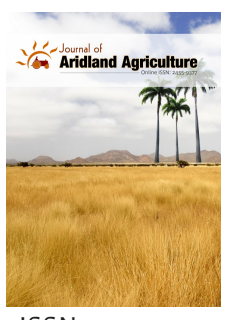

ISSN: $2455-9377$

\title{
Vertical distribution of soil nutrients under different land use systems in Bangladesh
}

\author{
Tahsina Sharmin Hoque', Shafia Afrin', Israt Jahan', Md Joinul Abedin Mian', \\ Mohammad Anwar Hossain*2
}

'Department of Soil Science, Bangladesh Agricultural University, Mymensingh 2202, Bangladesh, ${ }^{2}$ Department of Genetics and Plant Breeding, Bangladesh Agricultural University, Mymensingh 2202, Bangladesh

\begin{abstract}
Soil depth can significantly influence the availability of nutrients in soil. An experiment was conducted with seven soil samples from seven land use types to observe the effect of soil depth on soil properties under various land use systems. Soil $\mathrm{pH}$, electrical conductivity (EC), organic matter, available phosphorus (P), available sulphur (S) and different forms of potassium $(\mathrm{K})$ such as water soluble, exchangeable and non-exchangeable were determined from the soil samples collected from four depths (viz. 0-10, 10-20, 20-30 and 30-40 cm). Soil pH varied from 6.30-7.39 irrespective of depths and land uses and it increased with increasing soil depth. Electrical conductivity of the soils ranged from $42-310 \mu \mathrm{S} \mathrm{cm}^{-1}$ and organic matter status of most of the soils was very low to medium. Both EC and organic matter content decreased with the increase in soil depth. Available P concentration showed no specific changing trend with soil depth whereas available $\mathrm{S}$ concentration under different land use systems decreased with increasing soil depth. The concentrations of water soluble, exchangeable and non-exchangeable $\mathrm{K}$ in soils varied from 12.30-39.60, 20.90-53.16 and 163.30-684.30 mg kg-1, respectively and showed no specific changing pattern with soil depth. Water soluble K content was higher in rice growing fertilizer and manure-treated soil but higher contents of exchangeable and non-exchangeable $\mathrm{K}$ were observed in banana growing soil. In rice growing soils, nutrient concentration is mostly higher in nitrogen $(\mathrm{N})$, $\mathrm{P}$ and $\mathrm{K}+$ farm yard manure (FYM) - treated plots compared to rice growing control plots.
\end{abstract}

KEYWORDS: Soil depth, land use system, available phosphorus, fractions of soil potassium, available sulphur

*Corresponding author: Mohammad Anwar Hossain E-mail: anwargpb@bau. edu.bd

Received: August 27, 2020 Revised: November 07, 2020 Published: November 16, 2020

\section{INTRODUCTION}

Soil is a dynamic body that attains its properties by pedogenic processes which are effective both temporally and spatially [1]. Due to the interaction between natural and anthropogenic management system, soil undergoes vertical exchange of materials [2] and as a result both physical and chemical changes take place from surface to subsoil. The distribution of elements in soil is considered as a function of geochemical and pedogenic processes acting over the parent material because nutrient stratification in soil has started at the same time with weathering and soil forming processes influenced by terrestrial plants and roots [1]. Soil nutrients play key roles in both nutrient cycling and soil plant feedback, and their availability is one of the most critical limiting factors to affect plant growth and net primary production [3]. The variation in landscape as well as in the topographic features influences spatial patterns of water movement in surface and subsurface areas affecting nutrient availability in soil [4]. According to [5], the spatial variation of nutrients in topsoil is due to the differences in parent material, climate, vegetation, topography, fertilizer application and land use.

Most of the plant roots are extended beyond the surface layer and they fulfill their nutrient requirements partially from subsurface layers of the soil [6]. A good-quality soil must provide plants with all the resources for the growth of root system like water, nutrients and air [7]. Proper knowledge and clear information of how total and plant-available soil nutrients vary across the land is necessary for rational management of soil fertility and nutrient toxicity. Plant nutrient management is principally governed by the level of nutrients in soil [1] and understanding soil properties and processes ensures remediation or reclamation of disturbed or damaged soils. Geographic distribution and availability of nutrients can contribute to improvement and sustainability of agriculture. Besides, the knowledge of vertical distribution of nutrients in soil is important for recommendation of fertilizer management practices [8], because by accurately mapping variations in nutrient contents in soil, fertilizer expenditure

Copyright: ๑) The authors. This article is open access and licensed under the terms of the Creative Commons Attribution License (http://creativecommons.org/licenses/by/4.0/) which permits unrestricted, use, distribution and reproduction in any medium, or format for any purpose, even commercially provided the work is properly cited. Attribution - You must give appropriate credit, provide a link to the license, and indicate if changes were made. 
can be minimized which eventually enhance crop yields and reduce environmental hazards [9].

Land use is one of the main drivers of many processes of environmental change, as it influences basic resources within the landscape, including the soil resources [10]. The expansion of cultivated areas can exert influence on soil nutrient content by reducing the composition of plant species, net primary productivity and nutrient cycling [11]. Human management systems such as frequent tillage operations for the purpose of cultivation, grazing or similar uses alter the proportion of many soil properties with changing depth [12]. Transformation, transfer and losses of nutrients are comparatively higher under cropland than other land-use types suggesting the prevalence of soil degradation as more lands are claimed for crop production [13]. Different land uses and management methods can induce changes in soil properties like alteration in organic matter dynamics and nutrient concentrations in soil and influence productivity $[14,15,16,17]$. Information regarding spatial distribution characteristics of soil nutrients and relationship between soil nutrients and land use can provide some important basis for ecological restoration and reconstruction of degraded ecosystem [18]. As land use planning should be done on the basis of physico-chemical properties and nutrient status of different horizons of soil, the variability in nutrient status in the vertical distribution ofsoil profile has a long term bearing on crop production. Bangladesh is principally an agrarian country characterized by rice-based agriculture dominated landscapes. Besides, a small portion of land is used for production of other cereal crops like wheat, pulses and horticultural crops. Crops vary in uptake of nutrients in different layers of a soil. For successful crop production and management practices in Bangladesh, it is necessary to understand the characteristics and spatial distribution of nutrients in the soils of various regions. Considering the above points, the present study was undertaken to investigate the status of soil $\mathrm{pH}$, electrical conductivity and organic matter content and to evaluate the distribution of available $\mathrm{P}$, available $\mathrm{S}$ and $\mathrm{K}$ fractions (water soluble, exchangeable and nonexchangeable) with changing soil depths under various land uses. This study will provide depth-wise specific information on soil properties and nutrient concentration due to land utilization for crop production in a Non-Calcareous Dark Grey Floodplain soil of Bangladesh.

\section{MATERIALS AND METHODS}

\section{Site Description and Soil Sample Collection}

Soil samples were collected from different plots of Bangladesh Agricultural University (BAU) farm, namely non-cultivated area, banana, lentil and wheat growing plots, rice growing control plots, NPKSZn and NPK+FYM treated rice growing plots. The experimental site belongs to Sonatala Soil Series of NonCalcareous Dark Grey Floodplain Soils of Old Brahmaputra Floodplain (AEZ-9). The sampling site was well drained and fairly leveled medium high land. Soil samples were taken from four different depths viz. 0-10 cm, 10-20 cm, 20-30 cm and
$30-40 \mathrm{~cm}$ with four replications. Finally, the number of soil samples was twenty eight.

\section{Soil Sample Preparation}

The collected soil samples were carried to the Soil Science Laboratory of BAU for physical and chemical analyses. Unwanted materials like stones, granules, plant parts, leaves etc. were discarded from the samples. The samples were then dried at room temperature, crushed, mixed thoroughly and sieved through a 10-mesh sieve. Composite samples were prepared by mixing the sieved soils of same depth plot $^{-1}$ and preserved in plastic containers for subsequent laboratory analyses. Each of the samples was the composite of four replicated samples of same depth.

\section{Soil Analysis}

Soil $\mathrm{pH}$ was determined by glass electrode $\mathrm{pH}$ meter as described by [19]. The EC of soil was measured by an EC meter maintaining 1:5 soil: water ratio. The content of organic carbon (C) in the soil was determined by wet oxidation method [20] and the organic matter status was calculated by multiplying the percent organic $\mathrm{C}$ with the van Bemmelen factor, 1.73. Available $\mathrm{P}$ was extracted from the soil by shaking with $0.5 \mathrm{M} \mathrm{NaHCO}_{3}$ solution at $\mathrm{pH} 8.5$ following Olsen method [21]. Available S in soil was determined by $\mathrm{CaCl}_{2}(0.15 \%)$ extraction method as suggested by [22]. Water soluble $\mathrm{K}$ was determined in 1:10 of soil:water extraction method [19]. The exchangeable K content in soil was measured by $1 \mathrm{MNH}_{4} \mathrm{OAc}(\mathrm{pH} 7.0)$ extraction method as described by [23]. Non-exchangeable $\mathrm{K}$ was obtained by subtracting the water soluble plus exchangeable $\mathrm{K}$ values from the value of $\mathrm{K}$ extracted with $1 \mathrm{M}$ boiling $\mathrm{HNO}_{3}$ method [24].

\section{Statistical Analysis}

The analytical data were tabulated for statistical analysis to obtain the level of significance using the MSTAT-computer package program developed by [25]. The differences among the treatment means were compared by Duncan's Multiple Range Test (DMRT) at $1 \%$ level of probability [26].

\section{RESULTS}

\section{Vertical Distribution of Soil pH}

Soil $\mathrm{pH}$ was slightly acidic to neutral that increased with increasing soil depths under various land use systems (Table 1). The pH values of non-cultivated, banana, lentil, wheat, control rice, NPKSZntreated rice and NPK +FYM-treated rice growing soils ranged from 6.99-7.13, 7.05-7.26, 7.12-7.39, 6.30-6.62, 6.44-6.89, 6.82-7.26 and 6.99-7.37, respectively from surface to subsurface layers. In case of all the land uses, the lowest $\mathrm{pH}$ was recorded at $0-10 \mathrm{~cm}$ depth while the highest $\mathrm{pH}$ was noted at 30-40 cm soil depth.

\section{Vertical Distribution of Soil EC}

Table 2 shows that EC gradually decreased with soil depths. The EC of non-cultivated, banana, lentil, wheat, control rice, 
NPKSZn-treated rice and NPK+FYM-treated rice growing plots ranged from 217-176, 142.10-62.49, 141.50-68.58, 86.07$42.43,102.60-47.50,310.30-156.80$ and $278.90-150.80 \mu \mathrm{S} \mathrm{cm}^{-1}$, respectively from surface to subsurface. For each of the land use systems, the maximum EC was found at $0-10 \mathrm{~cm}$ depth whereas the minimum EC was recorded at $30-40 \mathrm{~cm}$ soil depth.

\section{Vertical Distribution of Soil Organic Matter}

Most of the soils under study had very low to medium organic matter content that decreased significantly with increasing depths in various land uses (Table 3). The organic matter status of noncultivated, banana, lentil, wheat, control rice, NPKSZn-treated rice and NPK+FYM-treated rice growing soils varied from 3.17-0.88\%, $1.31-0.36 \%, 1.78-0.50 \%, 1.54-0.36 \%, 2.82-0.57 \%, 2.77-1.37 \%$ and $2.89-1.25 \%$, respectively from top layer to subsurface layer.

\section{Vertical Distribution of Soil Available P}

The available $P$ in soil was influenced remarkably and significantly with different depths under land uses (Table 4). In non-cultivated soil, the contents of available $\mathrm{P}$ were 5.08,4.19, 2.67 and $1.64 \mathrm{mg} \mathrm{kg}^{-1}$ at $0-10 \mathrm{~cm}, 10-20 \mathrm{~cm}, 20-30 \mathrm{~cm}$ and $30-40$ $\mathrm{cm}$ depths, respectively. Phosphorus status in cultivated soils increased up to $20 \mathrm{~cm}$ depth and decreased from $20 \mathrm{~cm}$ below. In banana, lentil, wheat, control rice, NPKSZn-treated rice and NPK+FYM-treated rice growing soils, the maximum available P contents at 10-20 cm depth were 13.03, 7.78, 4.72, 3.77, 3.47 and $4.73 \mathrm{mg} \mathrm{kg}^{-1}$, respectively whereas the minimum available P contents at 30-40 cm depth were 6.53, 3.74, 4.12, 1.74, 1.56 and $1.48 \mathrm{mg} \mathrm{kg}^{-1}$, respectively.

\section{Vertical Distribution of Soil Available S}

The current study demonstrated that available $\mathrm{S}$ content in soil decreased significantly with increasing depths at various land uses (Table 5). The available $\mathrm{S}$ contents in non-cultivated, banana, lentil, wheat, control rice, NPKSZn-treated rice and $\mathrm{NPK}+\mathrm{FYM}$-treated rice growing soils ranged from 24.49-8.64, $12.56-3.99,15.85-4.56,14.89-5.52,11.38-3.69,16.26-4.76$, and 23.11-7.39 $\mathrm{mg} \mathrm{kg}^{-1}$, respectively from surface to subsurface layer. For all the land uses, the highest available $\mathrm{S}$ was found

Table 1: Depth-wise distribution of soil pH under various land use systems

\begin{tabular}{|c|c|c|c|c|c|c|c|}
\hline \multirow[t]{2}{*}{ Depth (cm) } & \multicolumn{7}{|c|}{ Soil pH } \\
\hline & Non-cultivated & Banana & Lentil & Wheat & Rice (control) & Rice (NPKSZn) & Rice (NPK+FYM) \\
\hline $0-10$ & $6.99^{c}$ & $7.05^{c}$ & $7.12^{c}$ & $6.30^{d}$ & $6.44^{d}$ & $6.82^{d}$ & $6.99^{d}$ \\
\hline $10-20$ & $7.04^{\mathrm{bc}}$ & $7.09^{c}$ & $7.16^{c}$ & $6.40^{c}$ & $6.58^{c}$ & $6.94^{c}$ & $7.11^{\mathrm{c}}$ \\
\hline $20-30$ & $7.09^{\mathrm{ab}}$ & $7.15^{\mathrm{b}}$ & $7.30^{\mathrm{b}}$ & $6.51^{b}$ & $6.78^{b}$ & $7.15^{\mathrm{b}}$ & $7.27^{b}$ \\
\hline $30-40$ & $7.13^{a}$ & $7.26^{a}$ & $7.39^{a}$ & $6.62^{\mathrm{a}}$ & $6.89^{a}$ & $7.26^{a}$ & $7.37^{a}$ \\
\hline $\operatorname{SE}( \pm)$ & 0.02 & 0.02 & 0.02 & 0.02 & 0.03 & 0.02 & 0.02 \\
\hline Level of significance & $* *$ & $* *$ & $* *$ & $* *$ & $* *$ & $* *$ & $* *$ \\
\hline CV\% & 0.20 & 0.13 & 0.25 & 0.33 & 0.61 & 0.62 & 0.30 \\
\hline
\end{tabular}

Figures in a column having common letter(s) do not differ significantly according to DMRT.

$* *=$ Significant at $1 \%$ level of probability; $C V=$ Co-efficient of variation; $\mathrm{SE}=$ Standard error of means

Table 2: Depth-wise distribution of soil EC $\left(\mu \mathrm{S} \mathrm{cm}^{-1}\right)$ under various land use systems

\begin{tabular}{|c|c|c|c|c|c|c|c|}
\hline \multirow{2}{*}{$\begin{array}{l}\text { Depth } \\
\text { (cm) }\end{array}$} & \multicolumn{7}{|c|}{ Soil EC $\left(\mu \mathrm{Scm}^{-1}\right)$} \\
\hline & Non-cultivated & Banana & Lentil & Wheat & Rice (control) & Rice (NPKSZn) & Rice (NPK+FYM) \\
\hline $0-10$ & $217.00^{a}$ & $142.10^{a}$ & $141.50^{a}$ & $86.07^{a}$ & $102.60^{a}$ & $310.30^{a}$ & $278.90^{\mathrm{a}}$ \\
\hline $10-20$ & $190.00^{\mathrm{b}}$ & $121.30^{\mathrm{b}}$ & $112.50^{\mathrm{b}}$ & $77.57^{\mathrm{b}}$ & $83.43^{b}$ & $271.70^{\mathrm{b}}$ & $235.40^{b}$ \\
\hline $20-30$ & $176.00^{c}$ & $77.06^{c}$ & $89.32^{c}$ & $57.47^{c}$ & $63.17^{c}$ & $188.10^{c}$ & $184.90^{c}$ \\
\hline $30-40$ & $152.70^{d}$ & $62.49^{d}$ & $68.58^{d}$ & $42.43^{d}$ & $47.50^{d}$ & $156.80^{d}$ & $150.80^{d}$ \\
\hline $\mathrm{SE}( \pm)$ & 1.32 & 0.75 & 0.44 & 0.64 & 0.65 & 0.44 & 0.77 \\
\hline Level of significance & $* *$ & $* *$ & ** & $* *$ & $* *$ & ** & $* *$ \\
\hline $\mathrm{CV} \%$ & 1.25 & 1.31 & 0.74 & 1.68 & 1.53 & 0.33 & 0.63 \\
\hline
\end{tabular}

Figures in a column having different letter(s) differ significantly according to DMRT. ** = Significant at $1 \%$ level of probability; CV = Co-efficient of variation; $\mathrm{SE}=$ Standard error of means

Table 3: Depth-wise distribution of organic matter (\%) in soil under various land use systems

\begin{tabular}{|c|c|c|c|c|c|c|c|}
\hline \multirow[t]{2}{*}{ Depth (cm) } & \multicolumn{7}{|c|}{ Organic matter (\%) } \\
\hline & Non-cultivated & Banana & Lentil & Wheat & Rice (control) & Rice (NPKSZn) & Rice (NPK+FYM) \\
\hline $0-10$ & $3.17^{\mathrm{a}}$ & $1.31^{\mathrm{a}}$ & $1.78^{\mathrm{a}}$ & $1.54^{\mathrm{a}}$ & $2.82^{\mathrm{a}}$ & $2.77^{\mathrm{a}}$ & $2.89^{a}$ \\
\hline $10-20$ & $2.54^{b}$ & $0.95^{b}$ & $1.40^{\mathrm{b}}$ & $1.40^{\mathrm{b}}$ & $1.94^{b}$ & $2.49^{b}$ & $2.58^{b}$ \\
\hline $20-30$ & $1.44^{c}$ & $0.57^{c}$ & $0.73^{c}$ & $0.59^{c}$ & $1.11^{\mathrm{c}}$ & $1.78^{c}$ & $2.16^{c}$ \\
\hline $30-40$ & $0.88^{d}$ & $0.36^{d}$ & $0.50^{d}$ & $0.36^{d}$ & $0.57^{d}$ & $1.37^{d}$ & $1.25^{d}$ \\
\hline $\operatorname{SE}( \pm)$ & 0.044 & 0.03 & 0.03 & 0.02 & 0.02 & 0.03 & 0.04 \\
\hline Level of significance & $* *$ & $* *$ & $* *$ & $* *$ & $* *$ & $* *$ & $* *$ \\
\hline CV\% & 3.89 & 7.03 & 4.96 & 4.97 & 2.51 & 2.42 & 3.17 \\
\hline
\end{tabular}

Figures in a column having different letter(s) differ significantly according to DMRT

$* *=$ Significant at $1 \%$ level of probability; $\mathrm{CV}=$ Co-efficient of variation; $\mathrm{SE}=$ Standard error of means 
at $0-10 \mathrm{~cm}$ depth while the lowest available $\mathrm{S}$ was recorded at 30-40 cm soil depth.

\section{Vertical Distribution of Water Soluble K in Soil}

Unlike other soils, the water soluble K contents in cultivated soils of dry land crops decreased up to $20 \mathrm{~cm}$ depth and again increased from $20 \mathrm{~cm}$ below (Table 6). The water soluble K contents in such soils used for cultivation of banana, lentil and wheat were 18.90, 13.50 and $12.60 \mathrm{mg} \mathrm{kg}^{-1}$, respectively at $0-10 \mathrm{~cm}$ depth which decreased $5.40,0.60$ and $0.30 \mathrm{mg} \mathrm{kg}^{-1}$, respectively at $10-20 \mathrm{~cm}$ depth. The maximum water soluble $\mathrm{K}$ contents at 30-40 depth in banana, lentil and wheat growing soils were $32.40,31.50$ and $32.70 \mathrm{mg} \mathrm{kg}^{-1}$, respectively. On the other hand, the water soluble K contents in noncultivated and wet land rice soils increased with the increase in soil depth. The water soluble K contents in non-cultivated, control rice, NPKSZn-treated rice and NPK+FYM-treated rice growing soils varied from 22.10-36.90, 17.70-37.20, 17.10-38.40 and 20.70-39.60 $\mathrm{mg} \mathrm{kg}^{-1}$, respectively from surface to subsurface layer.

\section{Vertical Distribution of Soil Exchangeable K}

In non-cultivated soil, the exchangeable $\mathrm{K}$ contents increased with increasing soil depth and were 36.30, 39.96, 40.70 and $42.90 \mathrm{mg} \mathrm{kg}^{-1}$ at $0-10 \mathrm{~cm}, 10-20 \mathrm{~cm}, 20-30 \mathrm{~cm}$ and $30-40$ $\mathrm{cm}$ depths, respectively (Table 7 ). In this soil, the highest exchangeable K was observed at 30-40 cm depth and the lowest was found at $0-10 \mathrm{~cm}$ depth. The exchangeable K content of the cultivated soils increased up to $20 \mathrm{~cm}$ depth and then decreased from $20 \mathrm{~cm}$ below. In banana, lentil, wheat, control rice, NPKSZn-treated rice and NPK+FYM-treated rice growing soils, the minimum exchangeable $\mathrm{K}$ contents at $0-10 \mathrm{~cm}$ depth were 26.40, 20.90, 24.94, 21.26, 22 and $24.56 \mathrm{mg} \mathrm{kg}^{-1}$, respectively and the maximum exchangeable $K$ contents at $10-20 \mathrm{~cm}$ depth were $51.34,40.70,50.60,42,45.76$ and $48.50 \mathrm{mg} \mathrm{kg}^{-1}$, respectively.

\section{Vertical Distribution of Soil Non-exchangeable K}

In all the studied soils, the fraction of non-exchangeable $\mathrm{K}$ increased up to $20 \mathrm{~cm}$ depth and then decreased from $20 \mathrm{~cm}$

Table 4: Depth-wise distribution of available $P\left(\mathrm{mg} \mathrm{kg}^{-1}\right)$ in soil under various land use systems

\begin{tabular}{|c|c|c|c|c|c|c|c|}
\hline \multirow[t]{2}{*}{ Depth (cm) } & \multicolumn{7}{|c|}{ Available $P\left(\mathrm{mg} \mathrm{kg}^{-1}\right)$} \\
\hline & Non-cultivated & Banana & Lentil & Wheat & Rice (control) & Rice (NPKSZn) & Rice (NPK+FYM) \\
\hline $0-10$ & $5.08^{a}$ & $9.41^{b}$ & $6.13^{b}$ & $4.54^{c}$ & $2.45^{c}$ & $2.19^{c}$ & $3.68^{b}$ \\
\hline $10-20$ & $4.19^{b}$ & $13.03^{a}$ & $7.78^{\mathrm{a}}$ & $4.72^{\mathrm{a}}$ & $3.77^{\mathrm{a}}$ & $3.47^{\mathrm{a}}$ & $4.73^{a}$ \\
\hline $20-30$ & $2.67^{c}$ & $8.63^{c}$ & $4.75^{c}$ & $4.69^{b}$ & $2.56^{b}$ & $2.69^{b}$ & $2.35^{c}$ \\
\hline $30-40$ & $1.64^{d}$ & $6.53^{d}$ & $3.74^{d}$ & $4.12^{d}$ & $1.74^{d}$ & $1.56^{d}$ & $1.48^{d}$ \\
\hline SE $( \pm)$ & 0.23 & 0.48 & 0.15 & 0.07 & 0.06 & 0.04 & 0.06 \\
\hline Level of significance & $* *$ & $* *$ & $* *$ & $* *$ & $* *$ & $* *$ & $* *$ \\
\hline CV\% & 11.52 & 8.89 & 4.84 & 2.30 & 4.41 & 2.93 & 3.87 \\
\hline
\end{tabular}

Figures in a column having different letter(s) differ significantly according to DMRT.

$* *=$ Significant at $1 \%$ level of probability; $\mathrm{CV}=$ Co-efficient of variation; SE = Standard error of means

Table 5: Depth-wise distribution of available $S\left(\mathrm{mg} \mathrm{kg}^{-1}\right)$ in soil under various land use systems

\begin{tabular}{|c|c|c|c|c|c|c|c|}
\hline \multirow[t]{2}{*}{ Depth (cm) } & \multicolumn{7}{|c|}{ Available S $\left(\mathrm{mg} \mathrm{kg}^{-1}\right)$} \\
\hline & Non-cultivated & Banana & Lentil & Wheat & Rice (control) & Rice (NPKSZn) & Rice (NPK+FYM) \\
\hline $0-10$ & $24.49^{a}$ & $12.56^{a}$ & $15.85^{a}$ & $14.89^{a}$ & $11.38^{\mathrm{a}}$ & $16.26^{a}$ & $23.11^{\mathrm{a}}$ \\
\hline $10-20$ & $16.50^{b}$ & $8.96^{b}$ & $11.17^{\mathrm{b}}$ & $11.34^{\mathrm{b}}$ & $8.63^{b}$ & $13.66^{b}$ & $16.39^{b}$ \\
\hline $20-30$ & $11.35^{c}$ & $6.75^{c}$ & $7.32^{c}$ & $8.81^{c}$ & $6.44^{c}$ & $8.43^{c}$ & $11.86^{c}$ \\
\hline $30-40$ & $8.64^{d}$ & $3.99^{d}$ & $4.56^{d}$ & $5.52^{d}$ & $3.69^{d}$ & $4.76^{d}$ & $7.39^{d}$ \\
\hline $\operatorname{SE}( \pm)$ & 0.71 & 0.30 & 0.38 & 0.12 & 0.12 & 0.10 & 0.24 \\
\hline Level of significance & $* *$ & $* *$ & $* *$ & $* *$ & $* *$ & $* *$ & $* *$ \\
\hline CV\% & 8.08 & 6.48 & 6.87 & 2.16 & 2.06 & 2.38 & 2.93 \\
\hline
\end{tabular}

Figures in a column having different letter(s) differ significantly according to DMRT.

$* *=$ Significant at $1 \%$ level of probability; CV $=$ Co-efficient of variation; SE $=$ Standard error of means

Table 6: Depth-wise distribution of water soluble $\mathrm{K}\left(\mathrm{mg} \mathrm{kg}^{-1}\right)$ in soil under various land use systems

\begin{tabular}{|c|c|c|c|c|c|c|c|}
\hline \multirow[t]{2}{*}{ Depth (cm) } & \multicolumn{7}{|c|}{ Water soluble $\mathrm{K}\left(\mathrm{mg} \mathrm{kg}^{-1}\right)$} \\
\hline & Non-cultivated & Banana & Lentil & Wheat & Rice (control) & Rice (NPKSZn) & Rice (NPK+FYM) \\
\hline $0-10$ & $22.10^{c}$ & $18.90^{\circ}$ & $13.50^{c}$ & $12.60^{c}$ & $17.70^{d}$ & $17.10^{c}$ & $20.70^{c}$ \\
\hline $10-20$ & $27.00^{b}$ & $13.50 \mathrm{~d}$ & $12.90^{c}$ & $12.30^{c}$ & $19.50^{c}$ & $19.80^{c}$ & $22.50^{c}$ \\
\hline $20-30$ & $27.30^{b}$ & $22.50^{b}$ & $22.80^{b}$ & $18.90^{\mathrm{b}}$ & $22.50^{\mathrm{b}}$ & $29.40 .^{b}$ & $35.10^{b}$ \\
\hline $30-40$ & $36.90^{\mathrm{a}}$ & $32.40^{a}$ & $31.50^{\mathrm{a}}$ & $32.70^{\mathrm{a}}$ & $37.20^{\mathrm{a}}$ & $38.40^{\mathrm{a}}$ & $39.60^{a}$ \\
\hline $\operatorname{SE}( \pm)$ & 0.46 & 0.44 & 0.67 & 0.65 & 0.21 & 1.08 & 0.64 \\
\hline Level of significance & $* *$ & $* *$ & $* *$ & $* *$ & $* *$ & $* *$ & $* *$ \\
\hline CV\% & 2.33 & 3.15 & 5.20 & 5.38 & 1.38 & 6.46 & 3.41 \\
\hline
\end{tabular}

Figures in a column having common letter(s) do not differ significantly according to DMRT.

$* *=$ Significant at $1 \%$ level of probability; $\mathrm{CV}=\mathrm{C} 0$-efficient of variation; SE = Standard error of means 
below (Table 8 ). In non-cultivated, banana, lentil, wheat, control rice, NPKSZn-treated rice and NPK+FYM-treated rice growing soils, the highest non-exchangeable $\mathrm{K}$ contents at 10-20 cm depth were $642.30,684.30,560.30,483.70,442,364.10$ and $403 \mathrm{mg} \mathrm{kg}^{-1}$, respectively and the lowest non-exchangeable $\mathrm{K}$ contents at 30-40 cm depth were 360.70, 482.70, 359.80, 203.30, 163.30, 203 and $351.40 \mathrm{mg} \mathrm{kg}^{-1}$, respectively.

\section{DISCUSSION}

In the present study, we reported on some soil properties and nutrient concentrations at several depths of a location and assess the effects of different land uses on soil properties and nutrient profiles. Soil properties like $\mathrm{pH}, \mathrm{EC}$, organic matter and different nutrient concentrations were affected by soil depth under various land use systems. The increase in $\mathrm{pH}$ with depth may be attributed to leaching of bases with percolation water and uptake by the crops and also decrease in organic matter accumulation with the depth. Besides, oxidation of ammonium to nitrate as well as ferrous ion to ferric hydroxide may cause the relatively lower $\mathrm{pH}$ of surface soil. In accordance with our results, some researchers $[6,9,27,28,29,30]$ also found increased soil $\mathrm{pH}$ at higher soil depth. In this study, soils from NPKSZn and NPKS+FYM treated rice growing plots showed higher $\mathrm{pH}$ than soils from rice growing control plots suggesting that chemical fertilizers and organic manures could alleviate soil acidity to some extent. This result is accorded to the findings of [31] who observed higher $\mathrm{pH}$ values in NPK and organic manure treated rice soil. Electrical conductivity was higher in top soil and it gradually decreased in deeper layers. Similar trend of EC with soil depth was also shown by $[9,29,32,33,34,35,36]$. Capillary rise of salt containing water and accumulation of salt due to evaporation may be the reason behind this [37]. The organic matter status of most of the soils was very low to medium and it decreased with the increase in soil depth which might be attributed to more addition of organic materials like stubbles, plant residues, manures etc. in top soil than subsoil. Our results are in accordance with the observations of $[9,15,38]$. The status of organic matter in noncultivated soil was the highest among all the land uses which is due to less disturbance of soil by tillage and more addition of leaf litter. Compared to soils of banana, lentil and wheat growing plots under aerated condition, the soils of rice growing plots under anaerobic condition contained higher amount of organic matter which might be due to less decomposition of organic matter under reduced condition.

In case of non-cultivated soils, the available $\mathrm{P}$ decreased from surface to sub-surface layer but in case of cultivated soils for crops (except banana), P decreased from $20 \mathrm{~cm}$ below. As suggested by some researchers $[6,39,40,41,42]$, the higher $\mathrm{P}$ content in surface soil may be due to the confinement of crop cultivation to the rhizosphere, presence of organic matter and supplementation of the depleted P by external sources like fertilizers and also due to presence of small amount of free iron oxide and exchangeable $\mathrm{Al}^{+3}$. Due to fixation of released $\mathrm{P}$ by clay minerals and oxides of iron and aluminium, sub-surface layers contained lower P than surface layer of soil [29,43]. For available $\mathrm{S}$ content of soil, our results are comparable with the results reported by $[29,42,44,45,46,47]$. High organic matter content, as well as addition of farm residues and S-containing fertilizers increases concentration of available $\mathrm{S}$ in the surface soil $[28,42,48]$. In our study, the non-cultivated soils showed higher available $\mathrm{S}$ value compared to cultivated soils. As reported by [49], cultivation decreases $\mathrm{S}$ concentration by 35 to $51 \%$ due to mineralization of organic S. Previously, [50] stated that loss

Table 7: Depth-wise distribution of exchangeable $\mathrm{K}\left(\mathrm{mg} \mathrm{kg}^{-1}\right)$ in soil under various land use systems

\begin{tabular}{|c|c|c|c|c|c|c|c|}
\hline \multirow[t]{2}{*}{ Depth $(\mathrm{cm})$} & \multicolumn{7}{|c|}{ Exchangeable $\mathrm{K}\left(\mathrm{mg} \mathrm{kg}^{-1}\right)$} \\
\hline & Non-cultivated & Banana & Lentil & Wheat & Rice (control) & Rice (NPKSZn) & Rice (NPK+FYM) \\
\hline $0-10$ & $36.30^{c}$ & $26.40^{c}$ & $20.90^{c}$ & $24.94^{d}$ & $21.26^{\mathrm{d}}$ & $22.00^{d}$ & $24.56^{d}$ \\
\hline $10-20$ & $39.96^{b}$ & $51.34^{\mathrm{a}}$ & $40.70^{a}$ & $50.60^{a}$ & $42.00^{\mathrm{a}}$ & $45.76^{a}$ & $48.50^{a}$ \\
\hline $20-30$ & $40.70^{a b}$ & $47.66^{b}$ & $35.20^{b}$ & $42.90^{b}$ & $39.50^{\mathrm{b}}$ & $40.70^{b}$ & $42.20^{b}$ \\
\hline $30-40$ & $42.90^{\mathrm{a}}$ & $43.16^{a}$ & $34.10^{b}$ & $40.70^{c}$ & $31.16^{c}$ & $32.60^{c}$ & $32.90^{c}$ \\
\hline $\operatorname{SE}( \pm)$ & 0.83 & 0.65 & 0.44 & 0.57 & 0.60 & 0.66 & 0.66 \\
\hline Level of significance & $* *$ & $* *$ & $* *$ & $* *$ & $* *$ & $* *$ & $* *$ \\
\hline CV\% & 3.97 & 2.82 & 2.57 & 2.76 & 3.18 & 3.63 & 3.90 \\
\hline
\end{tabular}

Figures in a column having common letter(s) do not differ significantly according to DMRT.

$* *=$ Significant at $1 \%$ level of probability; $\mathrm{CV}=$ Co-efficient of variation; $\mathrm{SE}=$ Standard error of means

Table 8: Depth-wise distribution of non-exchangeable $\mathrm{K}\left(\mathrm{mg} \mathrm{kg}^{-1}\right)$ in soil under various land use systems

\begin{tabular}{|c|c|c|c|c|c|c|c|}
\hline \multirow[t]{2}{*}{ Depth (cm) } & \multicolumn{7}{|c|}{ Non-exchangeable $\mathrm{K}\left(\mathrm{mg} \mathrm{kg}^{-1}\right)$} \\
\hline & Non-cultivated & Banana & Lentil & Wheat & Rice (control) & Rice (NPKSZn) & Rice (NPK+FYM) \\
\hline $0-10$ & $602.30^{b}$ & $643.70^{\mathrm{b}}$ & $403.20^{b}$ & $443.00^{b}$ & $402.70^{b}$ & $361.60^{\mathrm{a}}$ & $381.30^{a}$ \\
\hline $10-20$ & $642.30^{a}$ & $684.30^{a}$ & $560.30^{a}$ & $483.70^{a}$ & $442.00^{a}$ & $364.10^{a}$ & $403.00^{b}$ \\
\hline $20-30$ & $397.70^{c}$ & $603.70^{c}$ & $362.30^{c}$ & $323.00^{c}$ & $283.00^{c}$ & $243.00^{b}$ & $362.00^{c}$ \\
\hline $30-40$ & $360.70^{d}$ & $482.70^{d}$ & $359.80^{c}$ & $203.30^{d}$ & $163.30^{d}$ & $203.00^{c}$ & $351.40^{c}$ \\
\hline $\operatorname{SE}( \pm)$ & 1.43 & 0.50 & 1.70 & 0.21 & 0.99 & 0.97 & 1.01 \\
\hline Level of significance & $* *$ & $* *$ & $* *$ & $* *$ & $* *$ & $* *$ & $* *$ \\
\hline CV\% & 0.50 & 0.14 & 0.70 & 0.10 & 0.53 & 0.58 & 0.42 \\
\hline
\end{tabular}

Figures in a column having common letter(s) do not differ significantly according to DMRT.

** = Significant at $1 \%$ level of probability; CV = Co-efficient of variation; SE = Standard error of means 
of $\mathrm{S}$ in cultivated soil was attributed to physical disruption of aggregates, accelerated mineralization rate of soil organic matter and reduced input of plant residues.

In this study, the decrease of water soluble $\mathrm{K}$ up to $20-30 \mathrm{~cm}$ depth in cultivated soil may be due to removal by crops under intensive cultivation and leaching from surface layer. Such irregular trend of water soluble $\mathrm{K}$ content was also observed by [28]. Higher values of water soluble K in subsurface horizons may be attributed to relatively higher amount of clay fractions and organic matter all along the profile depth and possibly more removal of water soluble $\mathrm{K}$ by crops under intensive cultivation from surface horizon than from subsurface horizons. The asymmetrical pattern of exchangeable $\mathrm{K}$ with soil depth due to variation in clay content and organic matter was observed by [27]. Again, [32,38,51] found higher exchangeable $\mathrm{K}$ with increasing soil depth. For rice soils, application of organic manure along with mineral fertilizers showed higher values of both water soluble and exchangeable $\mathrm{K}$ compared to control soils. As demonstrated by [52], the increase in $\mathrm{K}$ content in NPK+ FYM-treated rice soil was due to larger amount of soil organic matter which adds additional amount of $\mathrm{K}$ and also provides sorption site for $\mathrm{K}$ on application of fertilizers and manures. In case of non-exchangeable $\mathrm{K}$ of soil, similar findings were previously reported by many researchers $[36,53,54,55,56]$. The surface soil contains higher non-exchangeable K compared to sub-surface soil which possibly might be due to more silt and clay content. Soils from non-cultivated and banana growing plots showed comparatively higher non-exchangeable K than other land uses which might be due to less removal by tillage operations. In a nutshell, surface soils and sub-surface soils differ in properties like $\mathrm{pH}, \mathrm{EC}$, organic matter and nutrient content as a result of variation in weathering of minerals, generation of leaf litter from different crops in cropping systems, release of nutrients from organic residues, application of fertilizers and upward translocation of nutrients from lower depth with capillary rise of ground water etc.

\section{CONCLUSION}

Knowledge of properties and nutrient distribution in soil has great relevance in assessing the long-term nutrient supplying capacity of soil for crops and is important in formulating a sound fertilizer program for a given set of soil and crop for long term sustainability. Soil depth affects soil properties and nutrient availability and thus plays a major role in influencing plant growth and yield. From the present study it can be concluded that under varying land uses, distribution of soil properties as well as nutrient elements is affected by soil depths. Soil $\mathrm{pH}$ was lower but EC and organic matter content were higher in the top soil compared to the deeper layers. Nutrient elements such as $\mathrm{P}, \mathrm{S}$ and most of the $\mathrm{K}$ fractions were higher in upper layers compared to subsurface soil showing variation among the land uses. The non-cultivated soil was more enriched with nutrient elements followed by banana and rice NPK+FYM treated soils. In future, a thorough study with soils of different locations may help the planners to formulate an effective nutrient fertilizer program for the region.

\section{REFERENCES}

1. Tomar, D., Bhat, M.A., Sahoo, J.,\& Sharma, M.K. (2020). Vertical distribution of nutrients vis-a-vis soil properties in different geomorphic units of north-eastern Haryana, India. Indian Journal of Ecology, 47(1), 58-67.

2. Assefa, A., \&Van Keulen, H. (2009). Modeling soil nutrient dynamics under alternative farm management practices in the Northern Highlands of Ethiopia. Soil and Tillage Research, 103, 203-215.

3. Matías, L., Castro, J., \&Zamora, R. (2011). Soil-nutrient availability under a global-change scenario in a Mediterranean mountain ecosystem. Global Change Biology, 17, 1646-1657.

4. Menezes-de-Souza, Z., Júnior, J.M., Pereira, G.T., \&Barbieri, D.M. (2006). Small relief shape variations influence spatial variability of soil chemical attributes. Scientia Agricola, 63(2): 161-168.

5. Wang, D., Fu, B.J., Zhao, W.W., Hu, H., \&Wang, Y. (2008).Multifractal characteristics of soil particle size distribution under different landuse types on the Loess Plateau, China. Catena, 72, 29-36.

6. Mishra, A., Pattnaik, T.M., Das, D., \&Das, M. (2015). Vertical distribution of available plant nutrients in soils of mid central valley at Odisha zone, India. American Journal of Experimental Agriculture, 7, 214-221.

7. Bortolanza, D.R., \&Klein, V.A. (2016). Soil chemical and physical properties on an Inceptisol after liming (surface and incorporated) associated with gypsum application. RevistaBrasileira de Ciencia do Solo, 40, e0150377.

8. Shankar, M.,\&Dhawal, K.S. (2009). Vertical distribution of available macro and micronutrients cation in red soils of Tamil Nadu. Asian Journal of Soil Science, 4(1), 118-120.

9. Patangray, A.J., Patil, N.G., Pagdhune, A.R., Singh, S.K., \&Mishra, V.N. (2018). Vertical distribution of soil nutrients and its correlation with chemical properties in soils of Yavatmal district, Maharashtra. Journal of Pharmacognosy and Phytochemistry, 7, 2799-2805.

10. González, A.P., de Abreu, C.A., Tarquis, A.M., \&Medina-Roldán, E. (2014). Impacts of land use changes on soil properties and processes. The Science World Journal, 2014, e831975.

11. Biro, K., Pradhan, B., Muchroithner, M., \&Makeschin, F. (2013). Land use/land cover change analysis and its impact on soil properties in the northern part of Gadarif region, Sudan. Land Degradation and Development, 24, 90-102.

12. MacCarthy, D.S., Agyare, W.A., Vlek, L.G., \&Adiku, G.K. (2013). Spatial variability of some soil chemical and physical properties of an agricultural landscape. West African Journal of Applied Ecology, 21, 47-61.

13. Adugna, A., \&Abegaz, A. (2015). Effects of soil depth on the dynamics of selected soil properties among the highlands resources of Northeast Wollega, Ethiopia: are these sign of degradation? Solid Earth Discussions, 7, 2011-2035.

14. Liu, X.L., He, Y.Q., Zhang, H.L., Schroder, J.K., Li, C.L., Zhou, J., \&Zhang, Z.Y. (2010). Impact of land use and soil fertility on distributions of soil aggregate fractions and some nutrients. Pedosphere, 20, 666-673.

15. Heshmati, M., Arifin, A., Shamshuddin, J., \&Majid, N.M. (2012). Predicting N, P, K and organic carbon depletion in soils using MPSIAC model at the Merek catchment, Iran. Geoderma, 175- 176: 64-77.

16. Navas, A., Gaspar, L., Quijano, L., López-Vicente, M., \&Machín, J. (2012). Patterns of soil organic carbon and nitrogen in relation to soil movement under different land uses in mountain fields (South Central Pyrenees). Catena, 94, 43-52.

17. Zhang, C., Liu, G.B., Xue, S., \&Sun, C.L. (2013). Soil organic carbon and total nitrogen storage as affected by land use in a small watershed of the Loess Plateau, China. European Journal of Soil Biology,54, 16-24.

18. Niu, X.Y., Wang, Y.H., Yang, H., Zheng, J.W., Zou, J., Xu, M.N., Wu, S.S., EXie, B. (2015). Effect of land use on soil erosion and nutrients in Dianchi lake watershed, China. Pedosphere,25(1), 103-111.

19. Jackson, M.L. (1973). Soil Chemical Analysis. New Delhi: Prentice Hall of India Pvt. Ltd, p. 98.

20. Walkley, A., \& Black, I.A. (1934). An experiment of the Degtjareff method for determining soil organic matter and a proposed modification of the chromic acid titration method. Soil Science, 37(1), 29-38.

21. Olsen, S.R., Cole, C.V., Watanabe, F.S., \& Dean, L.A. (1954). Estimation of available phosphorus in soils by extraction with sodium bicarbonate. Circular, USDA, p. 929. 
22. Williams, C.H., \& Sterinbergs, A. (1959). Soil fractions as chemical indices of available sulphur in some Australian soils. Australian Journal of Agricultural Research, 10, 340-352.

23. Knudsen, D., Peterson, G.A., \& Pratt, P.F. (1982). Lithium, sodium and potassium. In: Page, A. L., Miller,R. H. \&Keeny,D. R. (eds.). Methods of Soil Analysis Part 2.Chemical and Microbiological Properties.Soil Science Society of America,Madson, WI. pp. 225-246.

24. Helmke, P.A., \& Sparks, D.L. (1996). Lithium, sodium, potassium, rubidium, and cesium. In: Sparks, D. L. (ed.): Methods of Soil Analysis. Part 3. Book Series No. 5, Madison, Soil Science Society of America, pp. 551-573.

25. Russel, D.F. (1986). MSTAT-C package programme. Crop and Soil Science Department, Michigan State University, USA

26. Gomez, K.A., \&Gomez, A.A. (1984). Statistical Procedure for Agricultural Research. International Rice Research Institute, John Willey and Sons, New York, USA.

27. Saini, J., \& Grewal, K.S. (2014). Vertical distribution of different forms of potassium and their relationship with different soil properties in some Haryana soil under different crop rotation. Advances in Plants and Agriculture Research, 2, 48-52.

28. Khanday, M.U., Ram, D., Wani, J.A., \& Ali, T. (2017). Vertical distribution of nutrient of the soils of Namblan sub-catchment of Jhelum basin of Srinagar district in Kashmir valley. International Journal of Current Microbiology and Applied Sciences, 6(4), 375-381.

29. Kumar, R., Singh, R.R., Singh, M., Prasad, N., Kumar, S., Kumar, Y., \& Tripathi, N.C. (2017). Distribution pattern of available nutrients and biological properties of soil in different location of Meerut and Bulandshahr district under rice-wheat cropping system. International Journal of Advanced Biological Research, 7(1), 163-167.

30. Barnes, P, Wilson B, \& Lockwood P. (2010). Vertical and horizontal distribution of soil properties influenced by individual trees in grazing landscapes of NSW Australia. 19th World Congress of Soil Science, Soil Solutions for a Changing World, Brisbane, Australia pp. 268-270.

31. Dong, W., Zhang, X., Wang, H., Dai, X., Sun, X., Qiu, W., \& Yang, F. (2012). Effect of different fertilizer application on the soil fertility of paddy soils in red soil region of southern China.PloSOne, 7(9), e44504.

32. Kundu, M.C., Hazra, G.C., Biswas, P.K., Mondal, S., \& Ghosh, G.K. (2014). Forms and distribution of potassium in some soils of Hooghly district of West Bengal. Journal of Crop and Weed, 10(2), 31-37.

33. Divya, M., Jagadeesh, B.R., Srinivasa, D.K., \& Yogesh, G.S. (2016). Effect of long term soil fertilizer application on forms and distribution of potassium in soil under rice- cowpea cropping system. An Asian Journal of Soil Science, 11(1), 9-19.

34. Ozlu, E., \& Kumar, S. (2018). Response of soil organic carbon, pH, electrical conductivity, and water stable aggregates to long-term annual manure and inorganic fertilizer. Soil Science Society of America Journal, 82, 1243-1251

35. Haque, M.A. (2018). Variation in salinity through the soil profile in south coastal region of Bangladesh. Journal of Bangladesh Academy of Sciences, 42, 11-23.

36. Patil, S., Jagadeesh, B.R., \& Patil, P.L. (2018). Forms and distribution of potassium in selected red soil series of Kavalur sub-watershed soils of Koppal district, Karnataka. International Journal of Chemical Studies, 6, 2173-2178.

37. Ghosh, B., Ali, M.N., \& Saikat, G. (2016). Response of rice under salinity stress: A review update. Rice Research: Open Access 4, 167.

38. Fetene, E.M., \& Amera, M.Y. (2018). The effects of land use types and soil depth on soil properties of Agedit watershed, northwest Ethiopia.Ethiopian Journal of Science and Technology, 11, 39-56.

39. Singh, V.N., \& Mishra, B.B. (2012). Pedogenetic characterization of old alluvial soils of Gendak command area of Bihar for evaluation of land suitability. Journal of the Indian Society of Soil Science, 44, 136-142.

40. Naidu, M.V.S., \& Sireesha, P.V.G. (2013). Studies on genesis, characterization and classification of soils in semi-arid agri-ecological region: A case study in Banaganapalle mandal of Kurnool district in
Andhra Pradesh. Journal of the Indian Society of Soil Science, 61(3), 167-178.

41. Satish, S., Naidu, M.V.S., \& Ramana, K.V. (2018). Vertical distribution of available nutrients in soils of Brahmanakotkur watershed of Kurnoo district in Andhra Pradesh. International Journal of Chemical Studies 6. 2916-2925.

42. Khanday, M.U., Wani, J.A., Ram, D., \& Kumar, S. (2018). Depthwise distribution of nutrients of soils of horticulture growing areas of Ganderbal district in Kashmir valley. Journal of Pharmacognosy and Phytochemistry, 7(14), 19-22.

43. Nazir, S., \& Wani, M. A. (2009). Forms of potassium and potassium absorption behavior of soil under different cropping sequences. SKUAST Journal of Research, 11(2), 133-137.

44. Padhan, D., Pradhan, A.K., Chakraborty, M., \& Sen, A. (2016) Assessment of the effects of land use pattern on distribution of sulphur fractions in soil. Journal of Applied and National Science,8, 1685-1691

45. Ghodke, S.K., Durgude, A.G., Pharande, A.L., \& Gajare, A.S. (2016) Depth wise sulphur status of presentative bench mark soil series of western Maharashtra region. International Journal of Agricultural Science, 8(52), 2386-2389.

46. Jat, H.S., Datta, A., Sharma, P.C., Kumar, V., Yadav, A.K., Choudhary, M., Choudhary, V., Gathala, M.K., Sharma, D.K., Jat, M.L. Yaduvanshi, N.P.S., Singh,G., \& McDonald, A. (2018). Assessing soil properties and nutrient availability under conservation agriculture practices in a reclaimed sodic soil in cereal-based systems of northwest India. Archives of Agronomy and Soil Science, 64(4), 531-545.

47. Bhoyar, K.D., Raut, M.M., Girdekar, S.B., \& Ghorpade, P.W. (2019). Status of different forms of sulphur under intensively soybean growing soils of Savner tehsil, district Nagpur. International Journal of Chemical Studies, 7(3), 43-47.

48. Patel, J.C. \& Patel, K.C. (2008). Profile distribution of different forms of sulphur in prominent soil series of South Gujarat. Asian Journal of Soil Science, 3, 24-31.

49. Kopittke, P.M., Dalal, R.C., \& Menzies, N.W. (2016). Sulfur dynamics in sub-tropical soils of Australia as influenced by long-term cultivation. Plant and Soil, 402, 211-219.

50. Wang, J., Solomon, D., Lehmann, J., Zhang, X., \& Amelung, W. (2006). Soil organic sulfur forms and dynamics in the Great Plains of North America as influenced by long-term cultivation and climate. Geoderma, 133, 160-172

51. Rao, K.N., Yeledhalli, N.A., \& Channal, H.T. (2013). Soil potassium dynamics under intensive rice cropping in TBP command area of north Karnataka. Asian Journal of Soil Science, 8(2), 319-324.

52. Singh, M., Ram S., Wanjari, R.H., \& Sharma, P. (2014). Balance and forms of potassium under rice-wheat system in a 40-year-old longterm experiment on Mollisols of Pantnagar. Journal of Indian Society of Soil Science, 62, 38-44

53. Raheb, A. \& Heidari, A. (2012). Effects of clay mineralogy and physico-chemical properties on potassium availability under soil aquic conditions.Journal of Soil Science and Plant Nutrition, 12(4), 747-761.

54. Panwar, J.K., \& Unni, S.P.K. (2018). Status and distribution study for different forms of potassium in the soils of Nignoti village of Indore district of western Madhya Pradesh, India. International Journal of Current Microbiology and Applied Science 7(4), 1579-1584.

55. Jadhao, S.D., Arjun, D., Mali, D.V., Singh, M., Kharche, V.K. Wanjari, R.H., Kadu, P.R., Sonune, B.A., \& Magare, P.N. (2018). Effect of long-term manuring and fertilization on depth wise distribution of potassium fractions under sorghum-wheat cropping sequence in Vertisol. Journal of Indian Society of Soil Science, 66(2), 172-181.

56. Karwade, S., Thombe, S., \& Patel, B. (2020). Distribution of different forms of soil potassium in surface and sub-surface layers of paddy growing areas of Nagpur district. Journal of Pharmacognosy and Phytochemistry, 9(2), 909-915. 